\title{
Insights in agricultural practices and management systems linked to microbiological contamination of lettuce in conventional production systems in Southern Brazil
}

Sabrina Bartz ${ }^{1}$, Claudia Titze Hessel ${ }^{1}$, Rochele de Quadros Rodrigues ${ }^{1}$, Anelise Possamai ${ }^{1}$, Fabiana Oliveira Perini ${ }^{1}$, Liesbeth Jacxsens ${ }^{3}$, Mieke Uyttendaele ${ }^{3}$, Renar João Bender ${ }^{2}$ and Eduardo César Tondo ${ }^{1 *}$

\begin{abstract}
Background: Three conventional lettuce farms were evaluated in Southern Brazil using a standardized selfassessment questionnaire with 69 indicators and a microbiological sampling plan in order to assess the status of current agricultural practices and management systems. The use of both tools aimed to identify the foremost contamination sources and control measures during the crop production. A total of 128 samples were taken (manure, soil, water, workers' hands and equipment, lettuce seedlings and lettuce heads) in four visits during the growth cycle of lettuces. Samples were analysed for hygiene indicators (E. coli) and presence of pathogens (Salmonella spp. and E. coli O157).

Results: Microbiological results indicated that $E$. coli counts were very low in all analysed samples and no pathogens were detected. These results could be explained partially because all farms had toilets near to the fields, they did not raise animals near the crops, fields were located in areas where flooding was not possible, they used organic fertilizers adequately composted, and irrigation water demonstrated good microbiological quality. The microbial results for manure and soil indicated that the composting time was of utmost importance to maintain minimal contamination levels for the duration of the cultivation period, as long as the quality of irrigation water was very important to prevent further contamination of the crop. On the other hand, the self-assessment questionnaire identified a moderate to high risk level concerning microbiological contamination in all evaluated farms, because they had no formal good agricultural practices implemented, technical support, water control, inspections, food safety registers or sampling plan for microbiological or chemical analyses.

Conclusion: These different results are important in order to provide information about the actual status of contamination (microbial sampling plan) and possible food safety problems in the future based on the results given by the questionnaire. Furthermore, the results of this study also highlighted the necessity to provide more safety during the fresh produce cultivation, being formal good agricultural practices implementation an important start to the fresh produce farms in Brazil, as well as to adopt a higher level of control activities in order to achieve lower risk levels.
\end{abstract}

Keywords: Conventional lettuce; Good agricultural practices; Microbiological contamination

\footnotetext{
* Correspondence: tondo@ufrgs.br

'Laboratório de Microbiologia e Controle de Alimentos, Instituto de Ciência

e Tecnologia de Alimentos, Universidade Federal do Rio Grande do Sul (ICTA/UFRGS), Av. Bento Gonçalves, 9500, prédio 43212, Campus do Vale,

Agronomia, Cep. 91501-970 Porto Alegre/RS, Brazil

Full list of author information is available at the end of the article
} 


\section{Background}

Fresh produce is frequently associated with healthy diets because their nutritional properties and global production and consumption has increased significantly in the last years around the world (FAOSTAT, 2013; Warriner et al., 2009; Aruscavage et al., 2006). Intensive production systems and the lack of reliable good agricultural practices in the field are some of the reasons for the worldwide increasing numbers of foodborne illnesses associated to fresh produce (EFSA, 2014; Oilamat and Holley, 2012; Warriner et al., 2009; Beuchat, 2006; Sivapalasingam et al. 2004; Beuchat, 1996). Fresh produce can become contaminated with pathogens at any step of the supply chain, mostly due to natural, human or environmental factors (Olaimat and Holley, 2012; Oliveira et al., 2012; Itohan et al., 2011; Taban and Halkman, 2011). As a consequence, several foodborne outbreaks associated with leafy greens have been reported as primarily caused by Salmonella spp. and pathogenic Escherichia coli (Callejón et al., 2015; Buchholz et al., 2011; Warriner et al., 2009; Delaquis et al., 2007; Stine et al., 2005; Buck et al., 2003).

In Brazil, as in many other countries, lettuce (Lactuca sativa L.) is one of the most consumed leafy vegetables, attributable to year round availability, low cost and nutritional factors (Abreu et al., 2010; Mocelin and Figueiredo, 2009; WHO et al. 2008; Mattos et al., 2007). The Brazilian lettuce cultivation system is predominantly done in open fields, which are located for the most part at urban surroundings. Generally the distribution system occurs without refrigeration at any step of the postharvest chain, in contrast to practices in the European Union and United States, where cold chain and advanced logistics systems are applied (Brasil, 2013; Salla and Costa, 2012).

Food Safety Management Systems, for example, Good Agricultural Practices (GAP), at farm level are able to prevent and reduce bacterial contamination of fresh produce (Morgharbel and Masson, 2005; CDC, 2003; FDA, 1998). A number of factors has been identified as sources of microbial contamination, for example: organic fertilizers, soil, workers and equipment and, most noteworthy, water. Water has been identified as one of the most important sources of contamination of fresh produce. Irrigation waters and the fresh produce rinsing waters are recurrently used devoid of any disinfecting treatment (Rodrigues et al., 2014; Olaimat and Holley, 2012; Salem et al., 2011; Allende et al., 2008; Beuchat, 2006; Anderson et al., 1997).

Based on these evidences, the objective of the present study was to evaluate the status of current agricultural practices and management systems of conventional lettuce farms in the State of Rio Grande do Sul (RS), Southern Brazil, in order to identify major bottlenecks during the crop growing time related to conceivable microbiological contaminations. Insights were disclosed by combining microbiological analyses with the diagnosis of the risk level at farm circumstances, the status of implemented control measures and assurance activities and the system outputs at three typical Brazilian farms.

\section{Methods}

\section{Characterization of the farms}

Three family managed, smallholdings (approximately 2 to 3 hectares of land) in which lettuce was grown in a conventional production system were involved in the present study. Further on these production units were denominated farm 1, 2 and 3. These farms were chosen because they had typical characteristics of small farms were conventional lettuces and other leafy greens are cultivated in Brazil and also due to their similar conditions in terms of lettuce production. Before sampling collection, the owners were contacted and agreed to cooperate in the research. One of the farms was located in the rural area of Porto Alegre, the capital city of Rio Grande do Sul, the southernmost State of Brazil. The other two farms were located in the rural area of Viamão, a city neighboring Porto Alegre. Their cultivation system was in a open field.

The lettuce seedlings used to start off the plantations were delivered to the farms by different commercial suppliers. There were no formal good agricultural practices implemented or any other voluntary standard certified at the farms in the course of the sampling period. The fertilization procedures of the production fields were similar in all three farms. Organic fertilizers, over 90 days composted chicken manure, were purchased from local suppliers. None of the farms produced any kind of organic fertilizer.

The lettuce fields were irrigated by overhead sprinkler systems and the water was pumped from ponds located adjacent and at a lower level of the cultivation areas.

In all three farms the workers' households were located near the fields (less than 100 meters apart) and were equipped with toilets. Besides the intensive rainfall during the sampling period, flooding did not occur or affect the production fields. The farmers, during the sampling period, did not have cattle, poultry or other livestock animals in breeding process at their premises.

\section{Microbiological sampling plan \\ Sampling locations and collection}

A microbiological sampling plan was used with the intent of identifying contamination sources in the current agricultural practices. The sampling locations were selected based on literature review related to potential risk factors which may contribute to the microbiological contamination of lettuce. These locations were 
identified as critical sampling locations (CSL's), i.e., sites in the production processes at which contamination, growth and/or survival of microorganisms may take place. In the present paper 12 CSL's were selected based on sources and potential risk factors of microbial contamination, starting from lettuce seedlings, soil and manure, irrigation and rinse waters, handlers, food contact equipment up to the final products (Rodrigues et al., 2014; Oilamat and Holley, 2012; Ilic et al., 2012).

The sampling period ranged from August to October 2012 and the microbial sampling plan was set up to obtain information about hygiene (E. coli) and safety levels (Salmonella spp., E. coli O157:H7). Samples of water, soil, manure, lettuce seedlings, lettuce heads, workers' hands and transport boxes were collected as previously described by Rodrigues et al. (2014).

All the samples were transported by car to the Laboratory of Microbiology and Food Control of the Institute of Food Science and Technology - ICTA/UFRGS inside thermal boxes. Analyses started in less than one hour after sampling.

\section{Microbiological analyses}

The analyses of microbiological parameters of each CSL are presented in Table 1. All the microbiological analyses were carried out according to Rodrigues et al. (2014).

\section{Diagnostic instrument used to measure the food safety management systems}

A questionnaire with 69 indicators was applied to gain insights into the level of the good agricultural practices and management system currently implemented on the farms, as previously described by Rodrigues et al. (2014). The questionnaires were answered by the farms' owners.

\section{Weather conditions}

Temperature and cumulative precipitation of the week prior to sampling and including the sampling day (8 days) were obtained from the National Institute for Meteorology of Brazil (Instituto Nacional de Meteorologia (INMET), http://www.inmet.gov.br/portal/). Table 2 shows the averages of temperature and precipitation during the sampling period.

\section{Statistical analyses}

Statistical analyses were performed with SPSS Statistics version 21 at $p<0.050$. Bivariate correlations between the indicators were determined by calculating the Spearman's Rho coefficient using the raw enumeration data. KruskalWallis or Mann-Whitney $U$ tests were used to evaluate the influence of different factors. Pair wise tests were performed to identify the significant differences between individual categories when significant differences were found. In case of 'n' pair wise comparisons,
Dunn-Sidak correction was applied, resulting in adjusted individual p' values: $\mathrm{p}^{\prime}=1-(1-\mathrm{p})^{1 / \mathrm{n}}$, in which $\mathrm{p}=0.050$ to obtain a family-wise error rate of $5 \%$.

\section{Results}

\section{Microbiological contamination}

The presence of $E$. coli in the collected samples from manure, manured soil before setting the lettuce plantlets into the field and soil along the growth cycle of the lettuce crops presented mostly counts below the detection limits (Table 3). The highest count of E. coli (2.00 $\left.\log _{10} \mathrm{CFU} / \mathrm{g}\right)$ was observed in two samples: one sample of manure and another of soil (Table 3). There was no significant difference in $E$. coli counts between manured soil and soil samples for the duration of the sampling period (Kendall's tau-c, $\mathrm{p}=0.803$ ). There were no significantly differences in E. coli counts in manure among farms (Kruskal-Wallis Test, $\mathrm{p}=0.368$ ). Salmonella spp. and E. coli O157:H7 were not found in any sample. The $E$. coli concentration along the growth cycle in manure, manured soil and soil in the three farms is demonstrated in Figure 1.

Lettuce seedlings were collected only at the time of planting the seedlings in the field. E. coli counts ranged from $<1.00 \log _{10} \mathrm{CFU} / \mathrm{g}$ to $2.30 \log _{10} \mathrm{CFU} / \mathrm{g}$ (average of $\left.1.43 \pm 0.75 \log _{10} \mathrm{CFU} / \mathrm{g}\right)$. The highest count was observed on seedlings at farm 1 . During the growth cycle of the lettuces, the $E$. coli distribution was similar (Kruskal-Wallis Test, $\mathrm{p}=0.560$ ) (Figure 2). However, the highest $E$. coli counts were observed two and one week before harvest. At harvest, all E. coli counts were below the detection limit (Figure 2). E. coli counts were similar on the lettuce head samples collected at all farms (Kruskal- Wallis Test, $\mathrm{p}=0.162$ ), ranging from $<1.00 \pm 0.00 \log _{10} \mathrm{CFU} / \mathrm{g}$ to $1.12 \pm 0.14 \log _{10}$ $\mathrm{CFU} / \mathrm{g}$. The rinsed lettuce heads presented E. coli counts below the detection limits and no pathogens were found on any sample of seedlings and lettuces.

Water samples collected from ponds, sprinklers and rinsing tanks presented low counts of E. coli and 88.5\% of the samples counts were below the detection limit (Table 3). Counts of positive samples ranged from 1 to $1.4 \log _{10} \mathrm{MPN} / 100 \mathrm{ml}$. No statistical differences were determined for $E$. coli among the three water sources during the growth cycle of the crop (Kruskal- Wallis Test, $\mathrm{p}=0.739$ ). No pathogens were detected in any analyzed sample. During the lettuce growth cycle, the distribution of $E$. coli showed no significant differences among farms and time of sampling (Kruskal- Wallis Test, $\mathrm{p}=0.212$ ). No pathogens were found in any water sample.

The samples of the transport boxes and workers' hands of the three farms were collected only at harvest. All samples showed $E$. coli counts below the detection limit (Table 3). 
Table 1 Description of Critical Sampling Location (CSLs), samples, periodicity, microbiological parameters, methodologies, results interpretation and references

\begin{tabular}{|c|c|c|c|c|c|c|c|}
\hline CSL & Description & Samples & Time & $\begin{array}{l}\text { Microbiological } \\
\text { parameters }\end{array}$ & Methodology & $\begin{array}{l}\text { Interpretation } \\
\text { of the results* }\end{array}$ & References \\
\hline \multirow[t]{3}{*}{1} & Manure & 3 samples & T0 & E. coli & ISO 21528-2:2004 & $10^{3} \mathrm{cfu} / \mathrm{g}$ & MAPA IN n46. (2011) \\
\hline & & & & E. coli O157:H7 & ISO 16654:2001 & $\mathrm{A} / 25 \mathrm{~g}$ & ND \\
\hline & & & & Salmonella spp. & ISO 6579:2002 & $\mathrm{A} / 25 \mathrm{~g}$ & MAPA IN n46. (2011) \\
\hline \multirow[t]{3}{*}{2} & Manured soil & 3 samples $\rightarrow 3 \times 3$ pooled & TO & E. coli & ISO 21528-2:2004 & $10^{3} \mathrm{cfu} / \mathrm{g}$ & MAPA IN n46. (2011) \\
\hline & & & & E. coli O157:H7 & ISO 16654:2001 & $\mathrm{A} / 25 \mathrm{~g}$ & ND \\
\hline & & & & Salmonella spp. & ISO 6579:2002 & $\mathrm{A} / 25 \mathrm{~g}$ & MAPA IN n46. (2011) \\
\hline \multirow[t]{3}{*}{3} & Soil & 3 samples $\rightarrow 3 \times 3$ pooled & $\mathrm{T} 1$ & E. coli & ISO 21528-2:2004 & $10^{3} \mathrm{cfu} / \mathrm{g}$ & MAPA IN n46. (2011) \\
\hline & & & $\mathrm{T} 2$ & E. coli O157:H7 & ISO 16654:2001 & $\mathrm{A} / 25 \mathrm{~g}$ & ND \\
\hline & & & T3 & Salmonella spp. & ISO 6579:2002 & $\mathrm{A} / 25 \mathrm{~g}$ & MAPA IN n46. (2011) \\
\hline \multirow[t]{3}{*}{4} & Seedlings in soil & 1 sample $\rightarrow 1 \times 3$ pooled & T0 & E. coli & ISO 21528-2:2004 & $10^{2} \mathrm{cfu} / \mathrm{g}$ & $\mathrm{RDC} \mathrm{n}^{\circ} 12(2001)$ \\
\hline & & & & E. coli O157:H7 & ISO 16654:2001 & $\mathrm{A} / 25 \mathrm{~g}$ & ND \\
\hline & & & & Salmonella spp. & ISO 6579:2002 & $\mathrm{A} / 25 \mathrm{~g}$ & RDC n¹2 (2001) \\
\hline 5 & Seedling & 1 sample & T0 & E. coli & ISO 21528-2:2004 & $10^{2} \mathrm{cfu} / \mathrm{g}$ & $\mathrm{RDC} \mathrm{n}^{\circ} 12(2001)$ \\
\hline \multirow[t]{3}{*}{6} & Lettuce & 3 samples $\rightarrow 3 \times 3$ pooled & $\mathrm{T} 1$ & E. coli & ISO 21528-2:2004 & $10^{2} \mathrm{cfu} / \mathrm{g}$ & $\mathrm{RDC} \mathrm{n}^{\circ} 12(2001)$ \\
\hline & & & $\mathrm{T} 2$ & E. coli O157:H7 & ISO 16654:2001 & $\mathrm{A} / 25 \mathrm{~g}$ & ND \\
\hline & & & T3 & Salmonella spp. & ISO 6579:2002 & $\mathrm{A} / 25 \mathrm{~g}$ & RDC n¹2 (2001) \\
\hline \multirow[t]{3}{*}{7} & Lettuce after washing & 3 samples $\rightarrow 3 \times 3$ pooled & $\mathrm{T} 3$ & E. coli & ISO 21528-2:2004 & $10^{2} \mathrm{cfu} / \mathrm{g}$ & $\mathrm{RDC} \mathrm{n}^{\circ} 12(2001)$ \\
\hline & & & & E. coli O157:H7 & ISO 16654:2001 & $\mathrm{A} / 25 \mathrm{~g}$ & ND \\
\hline & & & & Salmonella spp. & ISO 6579:2002 & $\mathrm{A} / 25 \mathrm{~g}$ & $\mathrm{RDC} \mathrm{n}^{\circ} 12(2001)$ \\
\hline \multirow[t]{3}{*}{8} & Rinse water & $100 \mathrm{ml}$ & T3 & E. coli & $20^{\mathrm{TH}} \mathrm{APHA}(1998)$ & $2 \times 10^{2} \mathrm{MPN} / 100 \mathrm{ml}$ & CONAMA. n³57 de 2005 \\
\hline & & & & E. coli O157:H7 & ISO 16654:2001 & $\mathrm{A} / 25 \mathrm{ml}$ & ND \\
\hline & & & & Salmonella spp. & ISO 6579:2002 & $\mathrm{A} / 25 \mathrm{ml}$ & ND \\
\hline \multirow[t]{3}{*}{9} & Irrigation water source & $100 \mathrm{ml}$ & T0 T1 & E. coli & $20^{\mathrm{TH}} \mathrm{APHA}(1998)$ & $2 \times 10^{2} \mathrm{MPN} / 100 \mathrm{ml}$ & CONAMA. n³57 de 2005 \\
\hline & & & $\mathrm{T} 2$ & E. coli O157:H7 & ISO 16654:2001 & $\mathrm{A} / 25 \mathrm{ml}$ & ND \\
\hline & & & T3 & Salmonella spp. & ISO 6579:2002 & $\mathrm{A} / 25 \mathrm{ml}$ & ND \\
\hline \multirow[t]{3}{*}{10} & Irrigation water & $100 \mathrm{ml}$ & T0 T1 & E. coli & $20^{\mathrm{TH}} \mathrm{APHA}(1998)$ & $2 \times 10^{2} \mathrm{MPN} / 100 \mathrm{ml}$ & CONAMA. n³57 de 2005 \\
\hline & & & $\mathrm{T} 2$ & E. coli O157:H7 & ISO 16654:2001 & $\mathrm{A} / 25 \mathrm{ml}$ & ND \\
\hline & & & T3 & Salmonella spp. & ISO 6579:2002 & $\mathrm{A} / 25 \mathrm{ml}$ & ND \\
\hline 11 & Swab of farmers' hands & $3 \times 25 \mathrm{~cm}^{2}$ & T3 & E. coli & $\begin{array}{l}\text { ISO 21528-2:2004 } \\
\text { and AOAC (1998) }\end{array}$ & $\begin{array}{l}\leq 0.7 \log \mathrm{cfu} / 25 \mathrm{~cm}^{2} \\
\text { (below detection) }\end{array}$ & Jacxsens. et al. (2010) \\
\hline 12 & $\begin{array}{l}\text { Swab of transport } \\
\text { boxes of lettuce }\end{array}$ & $3 \times 50 \mathrm{~cm}^{2}$ & $\mathrm{~T} 3$ & E. coli & ISO 21528-2:2004 & $\begin{array}{l}\leq 0.7 \log \mathrm{cfu} / 25 \mathrm{~cm}^{2} \\
\text { (below detection) }\end{array}$ & Jacxsens. et al. (2010) \\
\hline
\end{tabular}

A: absent; ND: not defined by official regulation

T0: At planting. T1: Two weeks before harvest. T2: One week before harvest. T3: At harvest.

\section{Weather parameters}

Regarding weather parameters (temperature and precipitation), results were significantly different (KruskalWallis Test, $\mathrm{p}<0.001$ ) among the farms and the sampling days throughout the sampling period (Table 2). At farm 1, on the first day of sampling (T0), the highest count of E. coli found on soil seedling samples was $2.30 \log _{10}$ $\mathrm{CFU} / \mathrm{g}$. On that day the amount of rain fall was, statistically, the lowest in comparison to the other sampling days (Mann-Whitney $U$ Test, $\mathrm{p}<0.001$ ) (Table 2; Figure 1). On the other farms, no statistical differences were observed both for $E$. coli counts and rain fall volumes during the sampling period.

Temperature at transplanting day was similar to temperatures observed at two and one week before harvest (Mann-Whitney $U$ Test, $\mathrm{p}=0.446, \mathrm{p}=0.64$, respectively) and significantly different from the harvest day (MannWhitney $U$ Test, $\mathrm{p}=0.002$ ). Between the sampling periods of one and two weeks before harvest, temperatures were as well significantly different (Mann-Whitney $U$ Test, 
Table 2 Mean and standard deviation of temperature and precipitation during sampling period in three farms producing conventional lettuces in Southern Brazil

\begin{tabular}{llll}
\hline Farm & Visit & Temperature $^{*}\left({ }^{\circ} \mathbf{C}\right)$ & Precipitation* $(\mathbf{m m})$ \\
\hline 1 & T0 & $18.01 \pm 2.58^{\mathrm{a}}$ & $0.58 \pm 1.31^{\mathrm{a}}$ \\
& T1 & $19.02 \pm 2.46^{\mathrm{b}}$ & $4.84 \pm 12.80^{\mathrm{b}}$ \\
2 & T2 & $19.24 \pm 1.96^{\mathrm{c}}$ & $9.65 \pm 13.97^{\mathrm{c}}$ \\
& T3 & $17.71 \pm 2.33^{\mathrm{d}}$ & $23.38 \pm 35.06^{\mathrm{d}}$ \\
& T0 & $19.02 \pm 2.46^{\mathrm{a}}$ & $4.84 \pm 12.80^{\mathrm{a}}$ \\
& T1 & $16.92 \pm 3.15^{\mathrm{b}}$ & $1.49 \pm 3.71^{\mathrm{b}}$ \\
& T2 & $21.70 \pm 1.99^{\mathrm{c}}$ & $5.66 \pm 6.93^{\mathrm{c}}$ \\
& T3 & $19.40 \pm 1.90^{\mathrm{d}}$ & $3.70 \pm 5.24^{\mathrm{d}}$ \\
& T0 & $19.02 \pm 2.46^{\mathrm{a}}$ & $4.84 \pm 12.80^{\mathrm{a}}$ \\
& T1 & $16.92 \pm 3.15^{\mathrm{b}}$ & $1.49 \pm 3.71^{\mathrm{b}}$ \\
& T2 & $21.70 \pm 1.99^{\mathrm{c}}$ & $5.66 \pm 6.93^{\mathrm{c}}$ \\
& T3 & $19.40 \pm 1.90^{\mathrm{d}}$ & $3.70 \pm 5.24^{\mathrm{d}}$ \\
\hline
\end{tabular}

$\overline{a, b, c, d}$ : Different letters indicate statistically significant differences between the different sampling period.

$\mathrm{p}=0.004$ ), however no significant difference was observed in E. coli counts on samples.

The rain fall amounts were similar between the transplanting day, one week before harvest and at harvest (Mann-Whitney $U$ Test, $\mathrm{p}=0.064$ and $\mathrm{p}=0.426$, respectively). However, two weeks before harvest the amount of rain fall was statistically higher when compared to one week before and at harvest (Mann-Whitney $U$ Test, $\mathrm{p}<0.01$ for both), but the $E$. coli counts remained similar.

\section{Diagnosis of the current good agricultural practices and management system}

The context of the farmers appraised revealed that the conventional lettuce farms had a high risk context towards microbiological safety and crop hygiene. The calculated averages for product and process characteristics reached an index of 3.0 for all the three farms, because they have similar products and production practices (Table 4).

Indicators of organization \& chain processing scored 2.46 (farm 1), 2.69 (farm 2) and 2.54 (farm 3), indicating moderate to high level of risk (Table 4). The riskiness of the organization of the farms was very similar, except for the indicators 'technical staff of the farm' and 'variability in workforce'. Farm 1 had a stable workforce and additionally technological insights were as well present. At farm 2 also a good technological staff was present, but the activities had to rely on part time working personnel. For farm 3 the situation was rather the opposite. Working personnel at the premises was already an effective and a stable workforce for a long period of time. Nonetheless, the technological knowledge was not present. The indicators at level 2 (moderate risk) were 'extent of power in supplier relationships' and 'logistic facilities' for all three farms. However, all the other indicators were classified as at high risk level (level 3) for the three farms (sufficiency of operator competences, extent of management commitment, degree of employee involvement, level of formalization, sufficiency supporting information systems, food safety information exchange, and inspections of food safety authorities).

The indicated levels of the control activities in the good agricultural practices of the farms are specified in Table 4. The mean score of the design or set-up of control activities was 1.53. An indication that these activities were absent (level 1) or conducted on a basic level, using historical and common knowledge (level 2), and no sector information or information from suppliers was applied (level 3), nor tailored to the farms own situation (level 4).

The profiles were very similar for all the three farms, though farm 3 differs from farms 1 and 2 on 'partial physical intervention' (rinsing step), because rinsing of the lettuce crops was not conducted at farm 3. Farms were operating mainly at basic level (level 1) with regards to items related to 'equipment hygienic design maintenance program', 'sanitation program', 'packaging equipment', 'water control', 'sampling for microorganisms', 'analyzing methods for pathogens' and 'corrective actions'. An indication that all these control activities were not in place on the three farms (Table 4).

The indicators 'storage facilities', 'personal hygiene', 'raw materials control', 'fertilizer program', 'irrigation method' were classified at level 2. That level suggests that these activities were performed based on the knowledge of the farmers and not based on inputs from guidelines, sector organizations or government (Table 4).

For the farms at which rinsing of the lettuce heads was implemented after harvest (farms 1 and 2), the rinsing was also done based on their individual knowledge. Supplier control of the seedlings and manure composting were well achieved (level 3 , best situation) because all farms bought seedlings from the same supplier and fertilizers had been already composted over 90 days before arrival to the farms.

Moreover, the actual operation of control activities was lower (averages of 1.43 for all three farms - Table 4) compared to the design or set-up of the control measures. This situation is indicating that the control measures were not implemented and applied in practice. Only the indicator 'compliance to producers' received a level 2, because the growers comply to their own working method.

Also assurance activities such as 'translation of stakeholder requirements', 'use of feedback information', 'validation activities' and 'verification activities', 'documentation system' and 'record keeping' were not present or had 
Table 3 Sampling location, sample type, number of samples and results for microbiological analysis

\begin{tabular}{|c|c|c|c|c|c|c|c|c|}
\hline \multirow[b]{3}{*}{$\overline{C S L}$} & \multirow[b]{3}{*}{ Sample } & \multirow[b]{3}{*}{$\mathrm{n}$} & \multicolumn{4}{|l|}{ Hygiene indicators } & \multicolumn{2}{|c|}{ Pathogen indicator } \\
\hline & & & \multirow[t]{2}{*}{ E. coli (mean and stdv) } & \multicolumn{3}{|c|}{ Number of samples per $E$. coli counts } & \multirow{2}{*}{$\begin{array}{l}\text { Salmonella } \\
\mathrm{A}^{*}{ }^{*}\end{array}$} & \multirow{2}{*}{$\begin{array}{l}\text { E. coli } \\
\text { O157:H } \\
\text { A/P* }\end{array}$} \\
\hline & & & & $<1.0 \log$ & $\geq 1.0$ and $<2.0 \mathrm{log}$ & $\geq 2.0$ and $<3.0 \log$ & & \\
\hline 1 & Manure & 9 & $1.11 \pm 0.33 \mathrm{cfu} / \mathrm{g}$ & 8 & 0 & 1 & A & A \\
\hline 2 & Manured soil & 9 & $<1.00 \pm 0.00 \mathrm{cfu} / \mathrm{g}$ & 9 & 0 & 0 & A & A \\
\hline 3 & Soil & 27 & $1.05 \pm 0.20 \mathrm{cfu} / \mathrm{g}$ & 23 & 3 & 1 & A & A \\
\hline 4 & Seedlings in soil & 3 & $1.43 \pm 0.75 \mathrm{cfu} / \mathrm{g}$ & 2 & 0 & 1 & A & A \\
\hline 5 & Seedlings & 3 & $1.00 \pm 0.00 \mathrm{cfu} / \mathrm{g}$ & 2 & 1 & 0 & A & A \\
\hline 6 & Lettuce & 27 & $1.06 \pm 0.22 \mathrm{cfu} / \mathrm{g}$ & 23 & 3 & 1 & A & A \\
\hline 7 & Lettuce after washing & 6 & $1.00 \pm 0.00 \mathrm{cfu} / \mathrm{g}$ & 5 & 1 & 0 & A & A \\
\hline 8 & Rinse water & 2 & $1.00 \pm 0.00 \mathrm{MPN} / 100 \mathrm{ml}$ & 2 & 0 & 0 & A & A \\
\hline 9 & Irrigation water source & 12 & $1.03 \pm 0.012 \mathrm{MPN} / 100 \mathrm{ml}$ & 10 & 2 & 0 & A & A \\
\hline 10 & Irrigation water from tap & 12 & $1.04 \pm 0.12 \mathrm{MPN} / 100 \mathrm{ml}$ & 10 & 1 & 1 & A & A \\
\hline 11 & Swab of farmers' hands & 9 & $1.00 \pm 0.00 \mathrm{cfu} / 25 \mathrm{~cm}^{2}$ & 9 & 0 & 0 & - & - \\
\hline 12 & Swab of transport boxes of lettuce & 9 & $1.00 \pm 0.01 \mathrm{cfu} / 25 \mathrm{~cm}^{2}$ & 9 & 0 & 0 & - & - \\
\hline Total & & 128 & & 112 & 11 & 5 & - & - \\
\hline
\end{tabular}

* A: absent in $25 \mathrm{~g}$ or $25 \mathrm{ml}$; P: presence in $25 \mathrm{~g}$ or $25 \mathrm{ml}$; stdv: standard deviation.

not been yet developed. An indication that the farms could not demonstrate that they were working correctly (mean level of 1 for all).

The system output of the current good practices for the conventional lettuce farms was also low (mean 1 for all the three farms). The reason for this was that no information was available about the system output: no inspection or audit was performed, no samples (for microbiological or chemical analyses) were taken, no visual quality was evaluated, and no non-conformities were recorded or evaluated. Consequently no actual evaluation of the system output could be completed (Table 4).

\section{Discussion}

In the present study low levels of microbiological contamination were found in samples collected from small farms producing conventional lettuces in Southern Brazil, even though a high risk context towards microbiological safety and crop hygiene was verified in all of them based on the self-assessment questionnaire. These different results may indicate that some good agricultural practices were in place, however no formal control was applied.

For example, low levels of contamination and the absence of Salmonella spp. and E. coli O157:H7 observed in manure were attributed to the fact that all farms purchased manure from commercial suppliers, which was already composted for over 90 days. Several authors described that adequate composting time will effectively reduce contamination (Oliveira et al., 2012; Fischer-Arndt et al., 2010; James, 2006; Millner, 2003; MAFF, 2000) and particular pathogens like E. coli and Salmonella spp. can

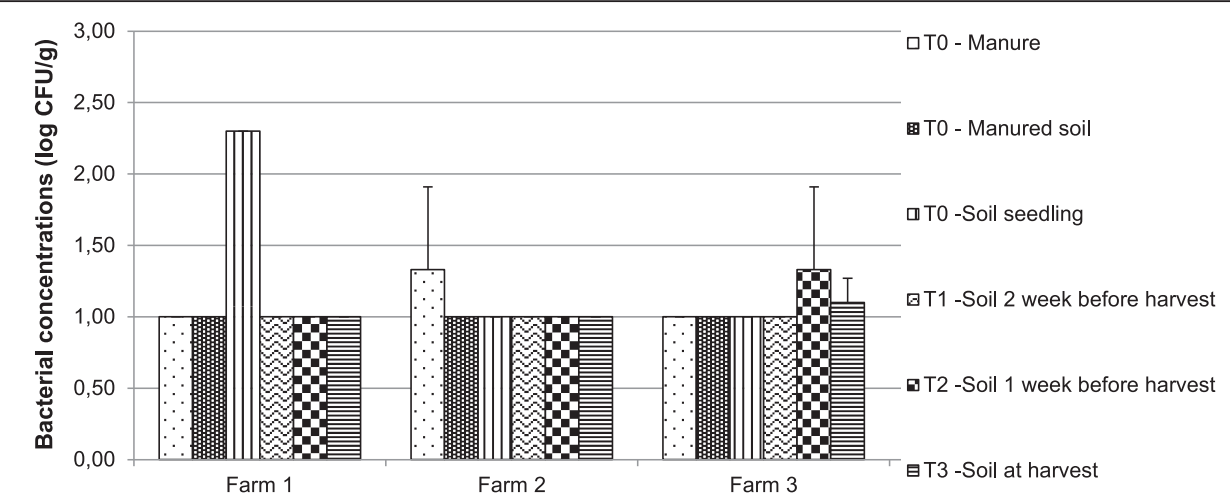

Figure 1 Overview of the performance of Escherichia coli enumeration among farms in manure, manured soil, soil seedling, soil two and one week before harvest and at harvest. 


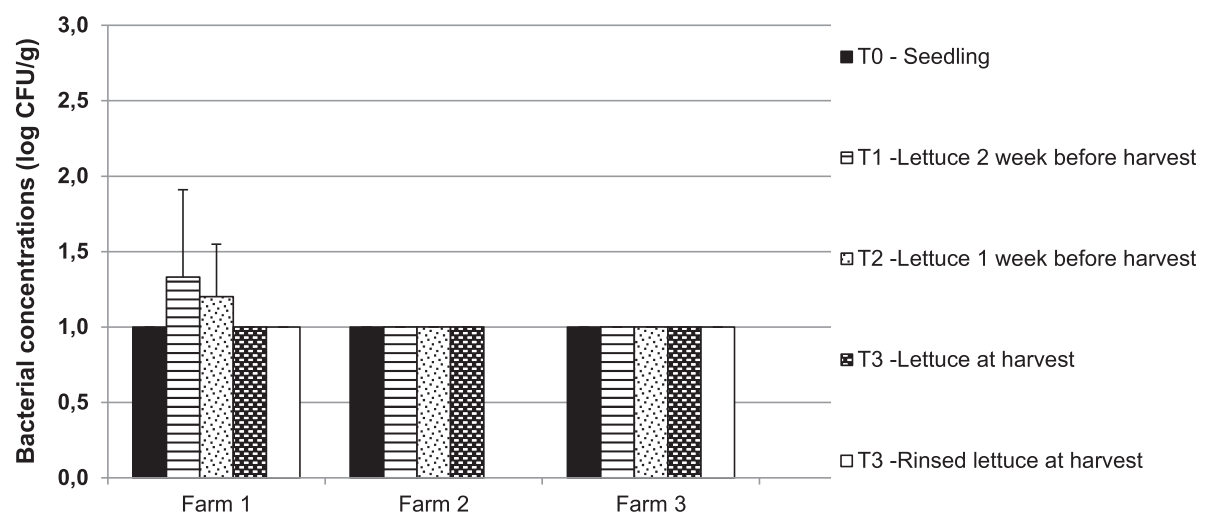

Figure 2 Overview of the performance of Escherichia coli enumeration among farms in seedling, lettuce two and one week before harvest, lettuce at harvest and rinsed lettuce at harvest.

survive at maximum to 90 days in soil as well as in manure (Heaton and Jones, 2007; Nicholson et al., 2005).

Moreover, the composted manures used at farms were added to the soil at least two weeks prior setting the seedlings into the field and after that no more manure was applied to supply nutrients to the lettuce plants. Also in the evaluation of the current good agricultural practices related to manure management, indicator 'organic fertilizer program', a moderate level 2 was given for the three farms, indicating that they used and manipulated manure based on generic knowledge from their suppliers (Table 4).

At planting and at harvest, all $E$. coli counts were below the detection limit $\left(<1.00 \log _{10} \mathrm{CFU} / \mathrm{g}\right)$, demonstrating good quality of lettuce seedlings and final product (lettuce) in attendance to the parameters of the Brazilian legislation (Brasil, 2001) that sets $10^{2} \mathrm{CFU} / \mathrm{g}$ as the maximum acceptable limit for $E$. coli counts. The fact that no $E$. coli was detected on lettuces can be attributed to the low pressure of $E$. coli in the manure, manured soil around the crop and low contamination of the irrigation water. Corroborating these results, EFSA (2014) reported that several reasons can be attributed to the variation in $E$. coli numbers on leafy greens and the relationship between primary production practices and numbers of $E$. coli in final product is very variable. Even though, it is difficult to define which is the main cause of this variation, the microbial quality of manure and irrigation water are frequently cited (EFSA, 2014).

In the present study, the water supply was considered a high risk (Table 4), especially because the water came from ponds (Richardson et al., 2009) and there was no further treatment, however water sampled from ponds, sprinklers and rinsing tanks presented low levels of contamination by $E$. coli. All analyzed samples were in accordance with the Brazilian regulation for irrigation of vegetables (CONAMA, 2005), which establishes a limit of $2 \times 10^{2} \mathrm{CFU} / 100 \mathrm{ml}$ for thermotolerant coliforms.
Similarly, no Salmonella spp. or E. coli O157:H7 were isolated from any of the analysed water samples. In a different study conducted in organic farms of the same region of Brazil (Rodrigues et al., 2014), the presence of Salmonella spp. and E. coli O157:H7 was detected in two samples (irrigation and rinsing tank water), after a flooding event. It is important to mention that in the farms investigated in the present study, the water supply (ponds) and the crop fields were located in elevated areas were flooding could not occur. Other authors observed the influence of flooding in the variation of pathogens levels (Liu et al., 2013, Castro-Ibañez et al., 2013; Cevallos-Cevallos et al., 2012; Tirado et al., 2010; Franz et al., 2005; Girardin et al., 2005; Rose et al., 2001).

Water has been identified as the source of microbial contamination of several foodborne outbreaks involving leafy vegetables around the world (Itohan et al., 2011; Delaquis et al., 2007; Beuchat, 1996). Pathogenic bacteria such as E. coli O157:H7 are often associated with outbreaks of waterborne diseases, resulting from inadequate treatments of the water used for irrigation and rinsing of fruits and vegetables (Levantesi et al., 2012; Moyne et al., 2011). Furthermore, in the present study, farms 1 and 2 used the same irrigation water source to rinse the lettuces after harvest. At farm 3 no rinsing of the lettuce heads did take place. The results indicated that no significant differences were observed for $E$. coli counts before, after or without the rinsing procedure, even though the water supply was considered a high risk of contamination (Table 4) and there was no water control.

No pathogens were identified in any crop sample and no increases in the microbial counts were as well observed after the rinsing process, demonstrating just the opposite in our study of what was ascertained in a study conducted by Antunes (2009).

Regarding organization and chain characteristics (Table 4), the technological staff present in farm 1 had received technical support provided by local government (city), while in 
Table 4 Scores and calculated mean attributed to the indicators of food safety management system

\section{Indicators \\ I. Context factors (overall) \\ Product and process characteristics \\ Risk of raw materials microbial}

Risk of final product microbial

Production system

3

Climate conditions

Water supply

Mean product and process

\section{Organization and chain}

Presence of technological staff

Variability in workforce composition

Sufficiency of operator competences

Extent of management commitment

Degree of employee involvement

Level of formalization

Sufficiency supporting information systems

Severity of stakeholders Requirements of

Extent of power in supplier relationships

Food safety information exchange

Logistic facilities

Inspections of food safety authorities

Supply source of initial materials

Mean organisation and chain

\section{Control activities design ${ }^{\text {b }}$}

Hygienic design of equipment and facilities

Maintenance and calibration program

Storage facilities

Sanitation program(s)

Farm1 Farm 2 Farm 3 Description of situation

33

Seedlings and manure purchased from commercial suppliers without any Good Agricultural Practice implemented. Irrigation water without any treatment. Seedlings in direct contact with soil.

33 The lettuces crops growing in direct contact with soil and without covering

33 Open cultivation field and contact with soil.

33 The farms were located in subtropical areas, with uncontrolled climate conditions.

33 All producers used water from ponds, without treatment.

$3,00 \quad 3,00$

33

Farm 1 had technical support provided by government department (of the city). Farm 2 and 3 had no technical support.

31

Farm 2 had a high turnover of employees and temporary operators were commonly used. Farm 1 and 3 had low turnover, with occasonaly temporary operators.

33 Operators with no training in food safety control, only practice experience in the field.

33 All three farms had no written food safety policy and no official quality team.

33 There was no safety control sistems implemented in the farms.

33 No meetings sistem implemented for instructions communication exist in all producers.

33 None of the producers had standard information system for food safety control decisions.

33 Steakholders did not ask for any QA requirements.

All farms required from their manure suppliers to compost the manure as a prerequisit for purchase.

33 No sistematic exchange of information on food safety issues were done with the suppliers of the three producers.

22 Transport of the final products to the distributer done by trucks in protected conditions (covered) but room temperature.

33

Never a inspection were done in the three farms.

11

Only local suppliers of major initial materials

$2,69 \quad 2,54$

11

None specific hygienic design required for equipement and facilities among the producers.

11 No manteinance and calibration program apllied in any of the producers.

22 Storage was made in ambient conditions in all farms.

11 The producers had no specific sanitation program implemented. 
Table 4 Scores and calculated mean attributed to the indicators of food safety management system (Continued)

\begin{tabular}{|c|c|c|c|c|}
\hline Personal hygiene requirements & 2 & 2 & 2 & $\begin{array}{l}\text { No specific hygiene instructions were followed by the } \\
\text { operators but washing facilities and toillets were available } \\
\text { next to the field in all farms. }\end{array}$ \\
\hline Incoming material control & 2 & 2 & 2 & $\begin{array}{l}\text { Incoming material control was done by visual inspections } \\
\text { based on historical experience in all farms. }\end{array}$ \\
\hline Packaging equipment & 2 & 2 & 2 & Use of non specific plastic boxes to pack the lettuce. \\
\hline Supplier control & 2 & 2 & 2 & The farms had no specific pre requisites for supplier selection. \\
\hline Organic fertilizer program & 2 & 2 & 2 & $\begin{array}{l}\text { Pre composted manure purchased from local suppliers } \\
\text { in all producers. }\end{array}$ \\
\hline Water control & 1 & 1 & 1 & There was no water control in all farms. \\
\hline Irrigation method & 2 & 2 & 2 & All producers used sprinkler as the irrigation method. \\
\hline Partial physical intervention & 2 & 2 & 1 & $\begin{array}{l}\text { General partial physical intervention applied by washing } \\
\text { the lettuce and external leaves removed }\end{array}$ \\
\hline Analytical methods to assess pathogens & 1 & 1 & 1 & $\begin{array}{l}\text { The presence of pathogens were never analyzed by } \\
\text { any of the producers. }\end{array}$ \\
\hline Sampling plan for microbial assessment & 1 & 1 & 1 & The producers had no sampling plan implemented. \\
\hline Corrective actions & 1 & 1 & 1 & The farms had no corrective actions described. \\
\hline Mean control activities design & 1,53 & 1,53 & 1,53 & \\
\hline \multicolumn{5}{|l|}{ III. Control activities operation ${ }^{\mathbf{b}}$} \\
\hline Actual availability of procedures & 1 & 1 & 1 & The procedures were not documented in all the three farms. \\
\hline The actual of compliance to procedures & 2 & 2 & 2 & $\begin{array}{l}\text { The operators executed tasks according to their own } \\
\text { experience and ad-hoc basis. }\end{array}$ \\
\hline $\begin{array}{l}\text { Actual hygienic performance of equipment } \\
\text { and facilities }\end{array}$ & 1 & 1 & 1 & $\begin{array}{l}\text { The hygienic design is not considered to be important } \\
\text { for food safety. }\end{array}$ \\
\hline Actual storage/cooling capacity & 1 & 1 & 1 & The farms had no cooling storage facility available. \\
\hline $\begin{array}{l}\text { Actual process capability of partial physical } \\
\text { intervention }\end{array}$ & 2 & 2 & 2 & $\begin{array}{l}\text { The partial physical intervention were done without } \\
\text { standard parameters and no control charts. }\end{array}$ \\
\hline Actual process capability of packaging & 2 & 2 & 2 & $\begin{array}{l}\text { Packaging were done without regular parameters and } \\
\text { based on the lettuce size. }\end{array}$ \\
\hline Actual performance of analytical equipment & 1 & 1 & 1 & No analytical analyses were done in all farms. \\
\hline Mean control Activities operation & 1,43 & 1,43 & 1,43 & \\
\hline \multicolumn{5}{|l|}{ IV. Assurance activities ${ }^{\text {b }}$} \\
\hline $\begin{array}{l}\text { Translation of stakeholder requirements into } \\
\text { own HSMS requirements }\end{array}$ & 1 & 1 & 1 & Stakeholder requirements were not present in all three farms. \\
\hline $\begin{array}{l}\text { The systematic use of feedback information } \\
\text { to modify HSMS }\end{array}$ & 1 & 1 & 1 & The farms had no HSMS implemented. \\
\hline Validation of preventive measures & 1 & 1 & 1 & $\begin{array}{l}\text { The producers had no preventive measures implemented } \\
\text { and validated. }\end{array}$ \\
\hline Validation of intervention processes & 1 & 1 & 1 & $\begin{array}{l}\text { Intervention processes have never been validated and } \\
\text { were done based on their own knowledge. }\end{array}$ \\
\hline Verification of people related performance & 1 & 1 & 1 & $\begin{array}{l}\text { The producers had no documented procedures described, } \\
\text { so no verification was done. }\end{array}$ \\
\hline $\begin{array}{l}\text { Verification of equipment and methods } \\
\text { related performance }\end{array}$ & 1 & 1 & 1 & $\begin{array}{l}\text { No procedures of verification for equipment and methods } \\
\text { were preformed in all producers. }\end{array}$ \\
\hline Documentation system & 1 & 1 & 1 & Documentation were not available in all the farms. \\
\hline Record keeping system & 1 & 1 & 1 & no record keeping system were present in all three farms. \\
\hline Mean assurance activities & 1,00 & 1,00 & 1,00 & \\
\hline \multicolumn{5}{|l|}{ Food safety management system Output ${ }^{c}$} \\
\hline Food safety Management System evaluation & 1 & 1 & 1 & $\begin{array}{l}\text { No inspection or audit of the Food Safety Management } \\
\text { System were done in all produceres. }\end{array}$ \\
\hline
\end{tabular}


Table 4 Scores and calculated mean attributed to the indicators of food safety management system (Continued)

\begin{tabular}{|c|c|c|c|c|}
\hline Seriousness of remarks of remarks & 1 & 1 & 1 & Audits on HSMS were never performed. \\
\hline $\begin{array}{l}\text { Hygiene related and microbiological } \\
\text { food safety }\end{array}$ & 1 & 1 & 1 & $\begin{array}{l}\text { No records of hygine related and microbiological food } \\
\text { safety complains were available in the farms. }\end{array}$ \\
\hline Chemical safety complaints of customers & 1 & 1 & 1 & $\begin{array}{l}\text { Chemical complains records were not avalilable in the } \\
\text { producers. }\end{array}$ \\
\hline Typify the visual quality complaints & 1 & 1 & 1 & $\begin{array}{l}\text { No records about quality complaints were available in } \\
\text { the farms. }\end{array}$ \\
\hline Product sampling microbiological performance & 1 & 1 & 1 & $\begin{array}{l}\text { The microbiological performance is not known once } \\
\text { no microbiological analyses were done on regular basis. }\end{array}$ \\
\hline Judgment criteria microbiological & 1 & 1 & 1 & Microbiological analyses were not performed in the farms. \\
\hline Non conformities & 1 & 1 & 1 & $\begin{array}{l}\text { The performance of the HSMS was not possible once } \\
\text { no coformities registration were available }\end{array}$ \\
\hline Mean food safety output & 1,00 & 1,00 & 1,00 & \\
\hline \multicolumn{5}{|c|}{$\begin{array}{l}\text { a Context factors: product and process characteristics and organization and chain characteristics were evaluated based on three risk levels: level } 1 \text { (low risk); level } \\
2 \text { (medium risk); and level } 3 \text { (high risk). } \\
\text { bII Control activities design: evaluates the designs of control activities; III evaluates the actual operation or implementation of control activities; IV evaluates the } \\
\text { assurance activities in good agricultural practices based on four levels: level } 1 \text { (non-existing or not implemented); level } 2 \text { (activities done at basic level based on } \\
\text { own knowledges and historical information); level } 3 \text { (activities implemented based on sector information or guidelines); level } 4 \text { (activities adapted and tailored to } \\
\text { the specific situation on the farm). } \\
\text { CIV Food safety system output indicators: evaluation based on external or governmental audits, records, microbial and chemical analysis: level } 1 \text { (not done or no } \\
\text { information available); level } 2 \text { (limited information available); level } 3 \text { (more systematic information is available); level } 4 \text { (systematic informations available and good } \\
\text { results are obtained). }\end{array}$} \\
\hline
\end{tabular}

farms 2 and 3 no technical support was given. At the same time, farm 1 and 3 had a stable workforce, while farm 2 demonstrated a high turnover. Some authors described that the stability of the workforce can help the companies to prevent food safety questions and problems (Kirezieva et al., 2013a; Luning et al., 2011). At the same time the other organization characteristics demonstrated that all farms were operating in a very low level of organization, what is common in family based companies (Lunning et al, 2011; Powell et al., 2011), with the operators without any king of food safety training, no safety control systems implemented or written, no standard information about safety control systems, stakeholders without any quality assurance required, transport of the final product without temperature control and no inspection done by official authorities. It is well known that a trained workforce can help the companies to implement the good agricultural practices, once the employees know their responsibilities with the food safety issues (Kirezieva et al., 2013b) and that governmental inspections are also important to assure the compliance of the companies with the good practices (Jafee and Masakure, 2005; Kierzieva et al., Kirezieva et al. 2013a). It has also been demonstrated that the practice of keeping registration and documents in the primary production level is not usual in other countries (Jevsnik et al., 2008; Nieto-Montenegro et al., 2008), however, this could be a good procedure to be implemented in Brazilian farms in order to reach higher food safety levels.

It might be assumed that the studied conventional lettuce farms were in a moderate to high level of risk in microbiological contamination due to product and process characteristics (Kirezieva et al., 2013b), once the seedling where purchased from commercial suppliers without formal good agricultural practices implemented, lettuce crops were in direct contact with soil, farmers located in subtropical areas without climate conditions control, there was no treatment of irrigation water, and the cultivation was in open fields (Table 4). That context level found in the three farms suggests that a medium to advanced level of good agricultural practices and management system should be present in order to have a good system output as described by authors such as Osés et al. (2012) and Kirezieva et al. (2013b). However, the good practices and management of all investigated farms were informal and very basic, which may implicate in a high risk of food safety problems (Uyttendaele et al., 2014). Moreover, in the conventional lettuce farms investigated, there was no system output because of the lack of registered information and controls. This results could be explained because in Brazil there is no governmental requirement for that and producers are not stimulated to make quality records. A similar situation was observed in organic farms in the same region of Brazil (Rodrigues et al., 2014). Different circumstances was reported by Kirezieva et al. (2015) for companies located in the European Union where lower to moderate risk of production and supply chain context was found because, among other factors, controlled water sources were used and the cultivation was done in a protected area. The microbial load and pressure in the conventional farms analysed in the present study were lower compared to the samples collected in organic farms studied by Rodrigues et al. (2014), who reported higher E. coli counts and also the presence of Salmonella and E. coli O157:H7. 
The major differences between conventional and organic farms studied in Southern Brazil were the manure and composting of manure, which was conducted by the organic farms themselves with uncontrolled manner while a good manure management and control was evaluated for the conventional farms. Also, no animals were present on conventional farms what may contributed in the reduction of E. coli pressure on the water sources. Furthermore, a good water quality was verified in conventional farms, what was not the case in the organic ones (Rodrigues et al., 2014).

\section{Conclusions}

The use of the risk based sampling plan in combination with the diagnostic questionnaire allowed to analyse the microbiological aspects and the status of management systems of conventional lettuce farms in Southern Brazil.

Although all farms had no formal good agricultural practices implemented and there was no technical support in any of them, the microbial parameters showed very low levels of contamination, including the final products (lettuce heads). These results are plausible for the reason that Brazilian regulatory bodies do not enforce the implementation of good agricultural practices, nonetheless farmers are frequently aware that farm organization and hygienic procedures are necessary in order to maintain food safety and good productive levels. As an example, all analyzed farms had toilets near to the fields, providing adequate personnel hygienic practices. Further, the farms did not raise animals such as cows, pigs and hens, ultimate sources of cross contamination of the fields, remarkably, as a consequence of rain falls. In addition, the fields were located in areas where flooding was not possible. Another important aspect to take into account, concerning the organic fertilizer that was appropriately composted, not impacting on the contamination of the crops. Similarly, the good quality of the irrigation waters used, evidenced by the microbial analyses, did not influence the contamination of the final product.

Good practices should be applied during all food chain, farm to fork. It has been observed that in the last years, outbreaks caused by fresh produce are increasing around the world, suggesting that, in that particular step of the chain, primary production, more efforts are needed in order to get more safety.

Even though the fact that all the microbial results were very low and no pathogen was determined in any of the analysed samples, attention should be given to the results of the self-assessment questionnaire that indicated moderate to high risk levels at all farms. These different results are important in order to provide information about the actual status of contamination (microbial sampling plan) and possible food safety problems in the future based on the results given by the questionnaire. Furthermore, the results of this study also highlighted the necessity to provide more safety during the fresh produce cultivation, based on the bottlenecks identified by the selfassessment questionnaire, being formal good agricultural practices implementation an important start to the fresh produce farms in Brazil, as well as to adopt a higher level of control activities in order to achieve lower risk levels.

\section{Competing interests}

The authors declare that they have no competing interests.

\section{Authors' contributions}

SB carried out initial contact with producers, performed sampling collection, carried out the microbial analyses, interviewed the producers with the self-assessment questionnaire, elaborated critical analyses based on results, drafted the manuscript. Carried out revisions on manuscript. CTH - Helped with the microbial and statistical analyses, participated in scientific discussions. RQ - Helped with the sample collection. AP - Prepared sampling material and contributed with for microbial analyses, participated in scientific discussions. FP - Prepared sampling material and contributed with for microbial analyses, participated in scientific discussions. $L J$ - Planned the sampling collection and general organization of experiments. Helped with the interpretation of the self-assessment questionnaire results and discussion. Participated in scientific discussions. MU - Planned the sampling collection and general organization of experiments. participated in scientific discussions. RJB - Revised the manuscript and added inputs. ECT organised research team in all activities of the manuscript. Planned the sampling collection and general organization of experiments. participated in scientific discussions. Contributed with laboratory infra-estructure. Participated in elaboration of the manuscript. All authors read and approved the final manuscript.

\section{Acknowledgements}

This research has been supported by the European Community's Seventh Framework Program (FP7) under grant agreement no. 244994 (project VEG-i-TRADE).

\section{Author details}

${ }^{1}$ Laboratório de Microbiologia e Controle de Alimentos, Instituto de Ciência e Tecnologia de Alimentos, Universidade Federal do Rio Grande do Sul (ICTA/UFRGS), Av. Bento Gonçalves, 9500, prédio 43212, Campus do Vale, Agronomia, Cep. 91501-970 Porto Alegre/RS, Brazil. ²Laboratório de Pós-Colheita, Faculdade de Agronomia, Universidade Federal do Rio Grande do Sul, Av Bento Gonçalves, 7712. 91540-000 Porto, Alegre/RS, Brazil. ${ }^{3}$ Department of Food Safety and Food Quality, Laboratory of Food Preservation and Food Microbiology, Faculty of Bioscience Engineering, Ghent University, Coupure Links, 653, 9000 Ghent, Belgium.

Received: 7 January 2015 Accepted: 18 March 2015

Published online: 02 May 2015

\section{References}

Abreu IMO, Junqueira AMR, Peixoto JR, Oliveira SA (2010) Qualidade microbiológica e produtividade de alface sob adubação química e orgânica. Ciênc Tec Alim 30:108-18

Allende A, Selma MV, Lopez-Galvez F, Villaescusa R, Gil MI (2008) Impact of wash water quality on sensory and microbial quality, including Escherichia coli cross-contamination, of fresh-cut escarole. J Food Prot 71:2514-8

American Public Health Association-APHA (1998) Standard Methods for the Examination of Water and Wastewater. 20 th ed. APHA, Washington, 10 cap Anderson SA, Turner SJ, Lewis GD (1997) Enterococci in the New Zealand environment: implications for water quality monitoring. Water Sci Tech 35:325-31, 10.1016/S0273-1223(97) 00280-1

Antunes MA (2009) Contaminação, crescimento e inativação de microrganismos na cadeia de produção de alface (Lactuca sativa L.) variedade Vitória de Santo. Dissertation, Federal University of Viçosa

AOAC International (1998) Official methods of analysis of AOAC international (20th ed.) Gaithersburg 
Aruscavage D, Lee K, Miller S, LeJeune JT (2006) Interactions affecting the proliferation and control of human pathogens on edible plants. J Food Sci 71(8):R89-99, 10.1111/j.1750-3841.2006.00157

Beuchat LR (2006) Vectors and condition for pre-harvest contamination of fruits and vegetables with pathogens capable of causing enteric diseases. British Food J 108:38-53

Beuchat LR (1996) Pathogenic microorganisms associated with fresh produce. J Food Prot 59:204-16

Buchholz U, Bernard H, Werber D, Böhmer MM, Remschmidt C, Wilking H, Deleré Y An der Heiden M, Adlhoch C, Dreesman J, Ehlers J, Ethelberg S, Faber M, Frank C, Fricke G, Greiner M, Höhle M, Ivarsson S, Jark U, Kirchner M, Koch J, Krause G, Luber P, Rosner B, Stark K, Kühne M (2011) German outbreak of Escherichia coli 0104:H4 associated with sprouts. N Engl J Med 365(19):1763-70, doi:10.1056/NEJMoa1106482

Brasil (2001) Agência Nacional de Vigilância Sanitária (ANVISA) (2001) Resolução RDC n 12, de 02 de janeiro de 2001. Regulamento Técnico sobre padrões microbiológicos para alimentos

Brasil (2013) Empresa Brasileira de Pesquisa Agropecuária - EMBRAPA (2013) Desempenho produtivo de cultivares de alface crespa. Boletim de Pesquisa e Desenvolvimento. ISSN $1677-2229$

Buck JW, Walcott RR, Beuchat LR (2003) Recent trends in microbiological safety of fruits and vegetables. Plant Health Progress doi:10.1094/PHP-2003-0121-01-RV

Callejón RM, Rodríguez-Naranjo MI, Ubeda C, Hornedo-Ortega R, Garcia-Parrilla MC, Troncoso AM (2015) Reported foodborne outbreaks due to fresh produce in the United States and European Union: trends and causes. Food Path Dis 12(1):32-8, 10.1089/fpd.2014.1821

CDC - Codex Alimentarius Commission (2003) Code of Hygienic Practice for Fresh Fruits and Vegetables Food and Agricultural Organization, Rome. Available via http://www.fao.org/ag/agn/CDfruits_en/others/docs/alinorm03a.pdf

Castro-Ibañez I, Gil MI, Allende A (2013) Impact of extreme climatic events on microbial safety of leafy greens: flooding. Paper presented at the IAFP Annual Meeting, Charlotte, North Carolina

Cevallos-Cevallos JM, Danyluk MD, Gu GY, Vallad GE, van Bruggen AHC (2012) Dispersal of Salmonella Typhimurium by rain splash onto tomato plants. J Food Prot 75:472-9

CONAMA (2005) Resolução 357 de 17 de março de 2005. Available via http://www.mma.gov.br/port/conama/legiabre.cfm?codlegi $=459$

Delaquis PS, Bach LD, Dinu LS (2007) Behavior of Escherichia coli O157:H7 in leafy vegetables. J Food Prot 70:1966-1974

EFSA - European Food Safety Authority (2014). Scientific Opinion on the risk posed by pathogens in food of non-animal origin. Part 2 (Salmonella and Norovirus in leafy greens eaten raw as salads). EFSA J:12 (3)

FAOSTAT (2013). Food and Agriculture Organization Corporate Statistical Database. In 541 http://faostat3.fao.org/home/index.html\#HOME.

FDA - The Food and Drug Administration (1998) Guide to Minimize Microbial food safety hazards for fresh fruits and vegetables. Available via http://www.fda.gov/downloads/Food/GuidanceComplianceRegulatorylnformation/ GuidanceDocuments/ProduceandPlanProducts/UCM169112.pdf

Fischer-Arndt M, Neuhoff D, Tamm L, Köpke U (2010) Effects of weed management practices on enteric pathogen transfer into lettuce (Lactuca sativa var. capitata). Food Contr 21(7):1004-10

Franz E, van Diepeningen AD, de Vos OJ, van Bruggen AH (2005) Effects of cattle feeding regimen and soil management type on the fate of Escherichia coli 0157:H7 and Salmonella enterica serovar Typhimurium in manure, manureamended soil, and lettuce. Appl Environ Microbiol 71:6165-74

Girardin H, Morris CE, Albagnac C, Dreux N, Glaux C, Nguyen-The C (2005) Behaviour of the pathogen surrogates Listeria innocua and Clostridium sporogenes during production of parsley in fields fertilized with contaminated amendments. Fems Microbiol Ec 54:287-95

Heaton JC, Jones K (2007) Microbial contamination of fruit and vegetables and the behaviour of enteropathogens in the phyllosphere: a review. J Appl Microbiol 104:613-26, doi:10.1111/j.1365-2672.2007.03587.x

Ilic S, Rajic A, Britton C, Grasso E, Wilkens W, Totton S, Wilhelm B, Waddell L, LeJeune J (2012) A scoping study characterizing prevalence, risk factor and intervention research, published between 1990 and 2010, for microbial hazards in leafy green vegetables. Food Contr 23:7-19, doi:10.1016/j.foodcont.2011.06.027

Itohan AM, Peters O, Kolo I (2011) Bacterial contaminants of salad vegetables in Abuja Municipal Area Concil. Nigéria Mal J Microbiol 7(2):111-4

Jacxsens L, Uyttendaele M, Devlieghere F, Rovira J, Oses Gomez S, Luning PA (2010) Food safety performance indicators to benchmark food safety output of food safety management systems. Int J Food Microbiol 141:S180-S187.
James J (2006) Microbial hazard identification in fresh fruits and vegetables. Wiley Interscience, Dublin

Jaffee S, Masakure O (2005) Strategic use of private standards to enhance international competitiveness: vegetable exports from Kenva and elsewhere. Food Pol 30(3):316-33

Javesnik M, Hlebec V, Raspor P (2008) Food safety knowledge and practices among food handlers in Slovenia. Food Cont 19(12):1107-18

Kirezieva $K$, Lunning PA, Jacxsens L, Allende A, Johanennssen GS, Tondo EC, Rajkovic A, Uyttendaele M, van Boekel MAJS (2015) Facotrs affecting the status of food safety management systems in the global fresh produce chain. Food Contr 52:85-97, doi:10.1016/j.foodcont.2014.12.030

Kirezieva K, Jacxsens L, Uyttendaele M, Van Boekel M, Luning P (2013)a Assessment of food safety management systems in the global fresh produce chain. Food Res Int 52(1):230-242. doi:10.1016/ j.foodres.2013.03.023

Kirezieva K, Nanyunja J, Jacxsens L, Uyttendaele M, Van der Vorst J, Luning P (2013b) Context factors affecting design and operation of food safety management systems in the fresh produce chain. Trends Food Sci Tech 32(2):108-27, doi:10.1016/j.tifs.2013.06.001

Levantesi C, Bonadonna L, Briancesco R, Grohmann E, Toze S, Tandoi V (2012) Salmonella in surface and drinking water: occurrence and water-mediated transmission. Food Res Int 45(2):587-602, doi:10.1016/j.foodres.2011.06.037

Liu C, Hofstra N, Franz E (2013) Impacts of climate change on the microbial safety of pre-harvest leafy green vegetables as indicated by Escherichia coli 0157 and Salmonella spp. Int J Food Microbiol 163:119-28

Luning PA, Marcelis WJ, van Boekel MAJS, Rovira J, Uyttendaele M, Jacxsens L (2011) A tool to diagnose context riskiness in view of food safety activities and microbiological safety output. Trends Food Sci Tech 22(1):S67-79, doi:10.1016/j.tifs.2010.09.009

MAFF, The Ministry of Agriculture Fisheries and Food (2000) A study of on-farm manure applications to agricultural land and an assessment of the risks of pathogen transfer into the food chain. Avaiable via http://www.safeproduce.eu/Pics/FS2526.pdf

Mattos LM, Moretti CL, Chitarra AB, Prado MET (2007) Qualidade de Alface Crespa Minimamente Processada Armazenada Sob Refrigeração em Dois Sistemas de Embalagem. Hort Bras 25(4):504-8

Millner P (2003) Composting: improving on a time-tested technique. Agric Res 51(8):20-1

Mocelin AFB, Figueiredo PMS (2009) Avaliação microbiológica e parasitológica das alfaces comercializadas em São Luiz - MA. Rev Inv Biom Uniceuma 1:97-107

Morgharbel ADI, Masson, ML (2005) Perigos associados ao consumo da alface, (Lactuca sativa), in natura. Available via http://serv-bib.fcfar.unesp.br/seer/ index.php/alimentos/article/viewFile/105/118

Moyne A, Sudarshana MR, Blessington T, Koike ST, Cahn MD, Harris LJ (2011) Fate of Escherichia coli 0157:H7 in field-inoculated lettuce. Food Microbiol 28(8). doi:10.1016/j.fm.2011.02.001

Nicholson FA, Groves SJ, Chambers BJ (2005) Pathogen survival during livestock manure storage and following land application. Bio Tech 96(2):135-43, doi:10.1016/j.biortech.2004.02.030

Nieto-Montenegro S, Brown JL, LaBorde LF (2008) Development and assement of pilot food safety educational materials and training strategies for Hispanic workers in the mushroom industry using the Health Action Model. Food Contr 19(6):616-33

Olaimat AN, Holley RA (2012) Factors influencing the microbial safety of fresh produce: a review. J Food Prot 32(1):1-19, doi:10.1016/j.fm.2012.04.016

Oliveira M, Viñas I, Usall J, Anguera M, Abadias M (2012) Presence and survival of Escherichia coli 0157:H7 on lettuce leaves and in soil treated with contaminated compost and irrigation water. Int J Food Microbiol 156(2):133-40, doi:10.1016/j.ijfoodmicro.2012.03.014

Osés SM, Luning PA, Jacxsens L, Santillana S, Jaime I, Rovira J (2012) Microbial performance of food safety management systems implemented in the lamb production chain. J Food Prot 75(1):95-103, doi:10.4315/0362-028X. JFP-11-263

Powell DA, Jacob CJ, Chapman BJ (2011) Enhancing food safety culture to reduce rates of foodbone illness. Food Contr 22(6):817-22

Richardson HY, Nichols G, Lane C, Lake IR, Hunter PR (2009) Microbiological surveillance of private water supplies in England: the impact of environmental and climate factors on water quality. Water Res 43(8):2159-68

Rodrigues RQ, Loiko MR, De Paula CMD, Hessel CT, Jacxsens L, Uyttendaele M, Bender RJ, Tondo EC (2014) Microbiological contamination linked to implementation of good agricultural practices in the production of organic lettuce in Southern Brazil. Food Contr 42:152-64, doi:10.1016/j.foodcont.2014.01.043 
Rose JB, Epstein PR, Lipp EK, Sherman BH, Bernard SM, Patz JA (2001) Climate variability and change in the United States: potential impacts on water- and foodborne diseases caused by microbiologic agents. Environ Health Perspct 109(2):211-21

Sala FC, Costa CP (2012) Retrospectiva e tendência da alfacicultura brasileira. Hort Bras 30:187-94

Salem IB, Ouardani I, Hassine M, Aouni M (2011) Bacteriological and physico-chemical assessment of wastewater in different region of Tunisia: impact on human health. BMC Res Notes 4(144). doi:10.1016/ S0168-1605(00)00288-9

Sivapalasingam S, Friedman CR, Cohen L, Tauxe RV (2004) Fresh produce: a growing cause of outbreaks of foodborne illness in the United States, 1973 through 1997. J Food Prot 67:2342-53

Stine SW, Song I, Choi CY, Gerba CP (2005) Application of microbial risk assessment to the development of standards for enteric pathogens in water used to irrigate fresh produce. J Food Prot 68:913-8

Taban BM, Halkman AK (2011) Do leafy green vegetables and their readyto-eat (RTE) salads carry a risk of foodborne pathogens? Anaerobe 17(6):286-7, doi:10.1016/j.anaerobe.2011.04.004

Tirado MC, Clarke R, Jaykus LA, McQuatters-Gollop A, Frank JM (2010) Climate change and food safety: a review. Food Res Int 43:1745-65

Uyttendaele M, Moneim AA, Ceuppens S, El Tahan F (2014) Microbiological safety of strawberries and lettuce for domestic consumption in Egypt. j Food Process. Technol 5:1-7, doi:10.4172/2157-7110.1000308

Warriner K, Huber A, Namvar A, Fan W, Dunfield K (2009) Recent advances in the microbial safety of fresh fruits and vegetables. In: Taylor SL (ed) Adv Food Nut, vol 57., pp 155-208

WHO, World Health Organization, Food and Agriculture Organization of the United Nations (2008) Microbiological risk assessment series: Microbiological hazards in fresh fruits and vegetables. Avaiable via http:// www.fao.org/ag/agn/agns/files/FFV_2007_Final.pdf

\section{Submit your manuscript to a SpringerOpen ${ }^{\circ}$ journal and benefit from:}

- Convenient online submission

- Rigorous peer review

- Immediate publication on acceptance

- Open access: articles freely available online

- High visibility within the field

- Retaining the copyright to your article

Submit your next manuscript at $>$ springeropen.com 